\title{
Hydrometallurgical Purification of Some Clay Deposits for High Temperature Applications
}

\author{
${ }^{1,2}$ D.O. FOLORUNSO, ${ }^{1}$ S. ARIBO, ${ }^{1,2,3}$ P. O. OLUBAMBI and ${ }^{1,2}$ J.O. BORODE \\ ${ }^{1}$ Department of Metallurgical and Materials Engineering, Federal University of Technology, \\ Akure, Nigeria \\ ${ }^{2}$ Africa Materials Science And Engineering Networks: A Carnegie-IAS (RISE) Networks \\ ${ }^{3}$ Department of Chemical and Metallurgical Engineering, Tshwane University of Technology, \\ Pretoria West, Pretoria, South Africa.
}

Corresponding Author: stdavies4ever@yahoo.com

Phone Number: +2348038204252

\begin{abstract}
The characterization of five different Nigerian clay deposits has been carried out by employing three different characterization techniques (X-ray Diffraction, X-ray Fluorescence and Scanning Electron Microscopy/EDX). The clays obtained from the various deposits were carefully prepared for the analyses and the results obtained were compared to confirm the consistency and reliability of the different methods employed. The results revealed the various desirable $\left(\mathrm{S}_{\mathrm{i}} \mathrm{O}_{2}\right.$ and $\left.\mathrm{Al}_{2} \mathrm{O}_{3}\right)$ and deleterious $\left(\mathrm{Fe}_{3} \mathrm{O}_{4}, \mathrm{~K}_{2} \mathrm{O}, \mathrm{MgO}, \mathrm{MnO}\right.$ and $\left.\mathrm{Na}_{2} \mathrm{O}\right)$ elements and compounds contained in the clay samples in the various proportions and the appropriate purification technique required for preparing the clays for high temperature applications. Consequent upon the identification of the deleterious impurities, oxalic acid at different concentrations was used to leach the impurities out of the various clays. However, three out of the five deposits were chosen for purification because they possess the least quantities of the most deleterious $\left(\mathrm{Fe}_{2} \mathrm{O}_{3}\right)$ of the impurities.
\end{abstract}

Keywords: $\quad$ Hydrometallurgy, Purification, High Temperature, Clay and Characterization. 


\section{INTRODUCTION}

Refractories are materials that can withstand high temperature and chemical attack in the severe conditions of working [1,2]. They are thermal insulators and therefore used for making furnace linings, kilns, nozzles for pouring molten metal, heat exchangers and driers, to mention a few $[3,4]$. Applications in furnaces include anything from primary metal melting, through to heat treatment, glass production and processing, ceramic component manufacture, many forms of chemical processing and testing $[5,6]$

The term "clay" refers to a naturally occurring material composed primarily of fine-grained minerals, which is generally plastic at appropriate water contents and will harden when dried or fired [7]. Although clay usually contains phyllosilicates, it may contain other materials that impart plasticity and harden when dried or fired.

Earlier works on various Nigerian refractory clay deposits have shown many of them to be unsuitable for refractory works in the as-mined states. They are either high or low in one or more of the important refractory properties desired for good refractory works, or they are completely lacking in them [8]. The unsuitability of the local clay deposits for refractory works in the asmined states has therefore prompted the need for this work, which is principally aimed at characterizing and subsequently purifying them in readiness for the production of materials for high temperature applications.

\section{MATERIALS AND METHOD}

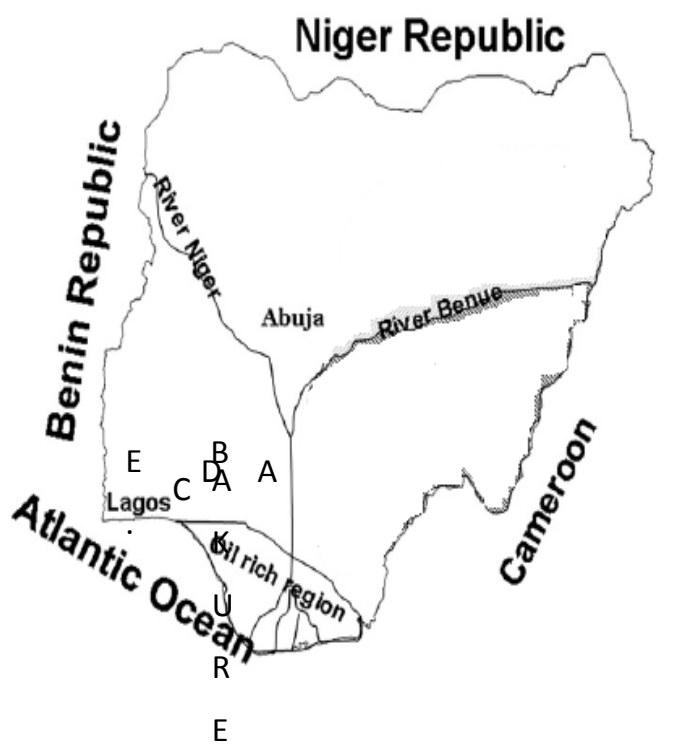

\section{Research Materials}

- Clays from:

Ifon in Ondo State (sample A)

Igbara-odo in Ekiti State, (B)

Ipetumodu in Osun State (C)

Isan-Ekiti in Ekiti State (D)

Iseyin in Oyo State, (E) 
Five Clay samples from five different clay deposits in different parts of the South - Western part of Nigeria were prepared for analysis. The clays were those from Iseyin in Oyo State, Ipetumodu in Osun State, Ifon in Ondo State, Igbara-Odo and Isan in Ekiti State. They are coded as listed above for ease of identification. A combination of X-ray Diffraction (XRD), X-ray Fluorescence (XRF) and Scanning Electron Microscopy (SEM) analyses were carried out to investigate the mineralogical composition of the five prepared samples (A-E) Hydrometallurgical purification was then employed to remove the identified impurities $\left(\mathrm{Fe}_{2} \mathrm{O}_{3}, \mathrm{MnO}, \mathrm{MgO}, \mathrm{Na}_{2} \mathrm{O}, \mathrm{CaO}\right)$ from the five samples.

\section{RESULTS AND DISCUSSION}

\subsection{XRF Elemental Analysis Studies}

The results of the X-ray fluorescence semi-quantitative analysis of the elements in the clay samples are as shown in Table 1.

The results show that sample A contains the highest amount of silica by mass (63.35\%), followed by sample E with $62.29 \%$ and with sample D having the least (54.67\%). Sample B contains the highest amount of Alumina (25.73\%) followed by sample C with $25.03 \%$ while sample A contains the least with $22.42 \%$. sample D indicated the highest amount of Ferric oxide (10.408\%), closely followed by sample B with $9.226 \%$ while sample A contains the least with just $6.109 \%$. sample B has the greatest quantity of $2.94 \%$ by mass of potassium oxide, followed by sample A with $2.878 \%$ while sample C contains the least amount of just $1.259 \%$. So also, sample D contains the highest amount of magnesium oxide (2.401\%) followed by sample A with $1.351 \%$ while sample C contains the least with just $0.91 \%$.

As clearly indicated in Table 1, all other minerals present are in such negligible proportion that their presence would not constitute threats to the performances of the clay as refractory materials.

Table 1: XRF semi-quantitative analysis of the elements

\begin{tabular}{|l|l|l|c|c|c|c|c|}
\hline Element & Compound & & Sample A & Sample B & Sample C & Sample D & Sample E \\
\hline $\mathrm{Al}$ & $\mathrm{Al}_{2} \mathrm{O}_{3}$ & (mass \%) & 22.42 & 25.737 & 25.03 & 23.98 & 22.729 \\
\hline $\mathrm{Si}$ & $\mathrm{SiO}_{2}$ & (mass \%) & 63.35 & 56.636 & 59.482 & 54.657 & 62.292 \\
\hline $\mathrm{Fe}$ & $\mathrm{Fe}_{2} \mathrm{O}_{3}$ & (mass \%) & 6.109 & 9.226 & 8.652 & 10.408 & 7.266 \\
\hline $\mathrm{K}$ & $\mathrm{K}_{2} \mathrm{O}$ & (mass \%) & 2.878 & 2.94 & 1.259 & 2.513 & 1.36 \\
\hline $\mathrm{Mg}$ & $\mathrm{MgO}$ & (mass \%) & 1.351 & 1.166 & 0.91 & 2.401 & 0.985 \\
\hline $\mathrm{Ba}$ & $\mathrm{Ba}$ & (mass \%) & 0.092 & 0.102 & 0.083 & 0.08 & 0.065 \\
\hline $\mathrm{Ca}$ & $\mathrm{CaO}$ & (mass \%) & 0.689 & 0.911 & 0.763 & 0.843 & 0.541 \\
\hline $\mathrm{Cl}$ & $\mathrm{Cl}$ & (mass \%) & ---- & 0.016 & 0.015 & 0.028 & 0.026 \\
\hline $\mathrm{Co}$ & $\mathrm{Co}$ & (mass \%) & ---- & 0.025 & 0.017 & 0.08 & 0.034 \\
\hline
\end{tabular}




\begin{tabular}{|l|l|c|c|c|c|c|c|}
\hline $\mathrm{Cr}$ & $\mathrm{Cr}_{2} \mathrm{O}_{3}$ & (mass \%) & 0.046 & 0.05 & 0.045 & 0.036 & 0.043 \\
\hline $\mathrm{Cu}$ & $\mathrm{Cu}$ & (mass \%) & 0.021 & 0.034 & 0.026 & 0.137 & 0.046 \\
\hline $\mathrm{Mn}$ & $\mathrm{MnO}$ & (mass \%) & 0.117 & --- & 0.045 & 0.109 & 0.05 \\
\hline $\mathrm{Na}$ & $\mathrm{Na}_{2} \mathrm{O}$ & (mass \%) & 0.789 & 1.229 & 0.372 & 0.604 & 0.259 \\
\hline $\mathrm{Ni}$ & $\mathrm{Ni}$ & (mass \%) & 0.064 & 0.042 & 0.078 & 0.061 & 0.074 \\
\hline $\mathrm{P}$ & $\mathrm{P}_{2} \mathrm{O}_{5}$ & (mass \%) & 0.109 & 0.051 & 0.047 & 0.049 & 0.058 \\
\hline $\mathrm{S}$ & $\mathrm{SO}_{3}$ & (mass \%) & 0.047 & 0.026 & 0.028 & 0.016 & 0.123 \\
\hline $\mathrm{Sr}$ & $\mathrm{Sr}$ & (mass \%) & 0.019 & ---- & 0.019 & 0.015 & 0.008 \\
\hline $\mathrm{Ti}$ & $\mathrm{TiO}_{2}$ & (mass \%) & 0.923 & 0.895 & 1.512 & 1.577 & 1.046 \\
\hline $\mathrm{Zr}$ & $\mathrm{Zr}$ & (mass \%) & 0.045 & 0.02 & 0.103 & 0.028 & 0.056 \\
\hline Total & & (mass \%) & 99.1 & 99.07 & 98.526 & 97.7 & 97.1 \\
\hline
\end{tabular}
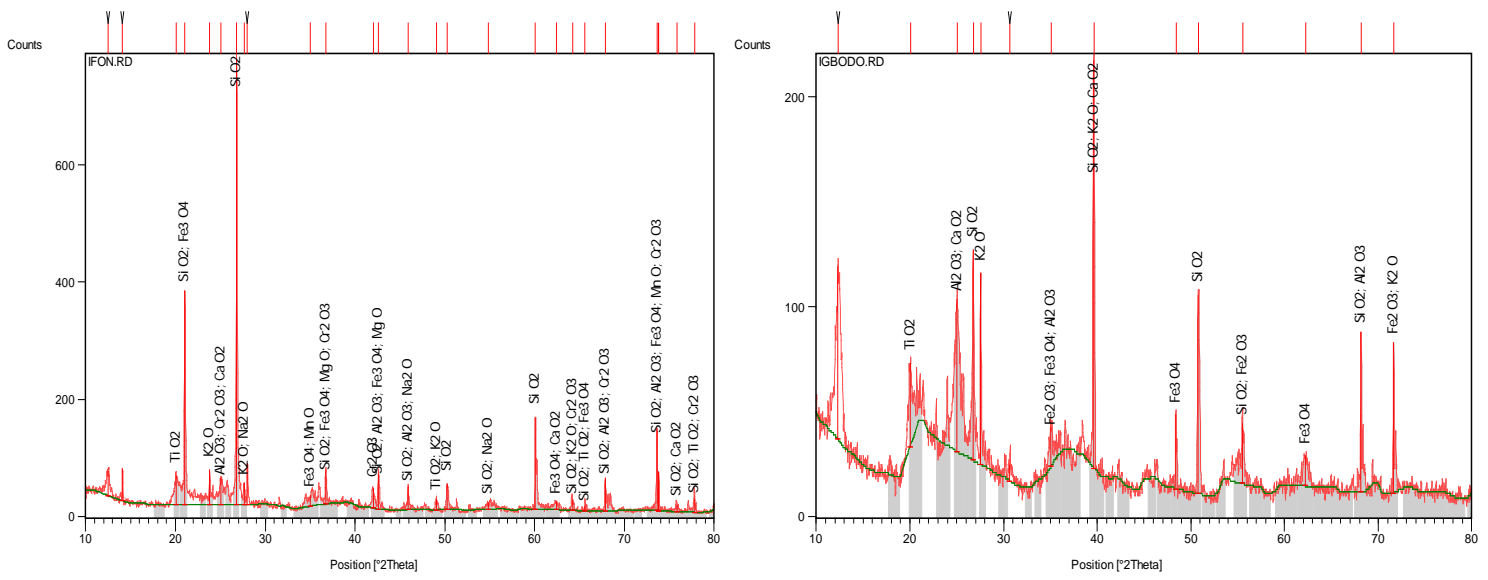

Figure 1: X-ray diffraction pattern of Sample A. Figure 2: X-ray diffraction pattern of sample B
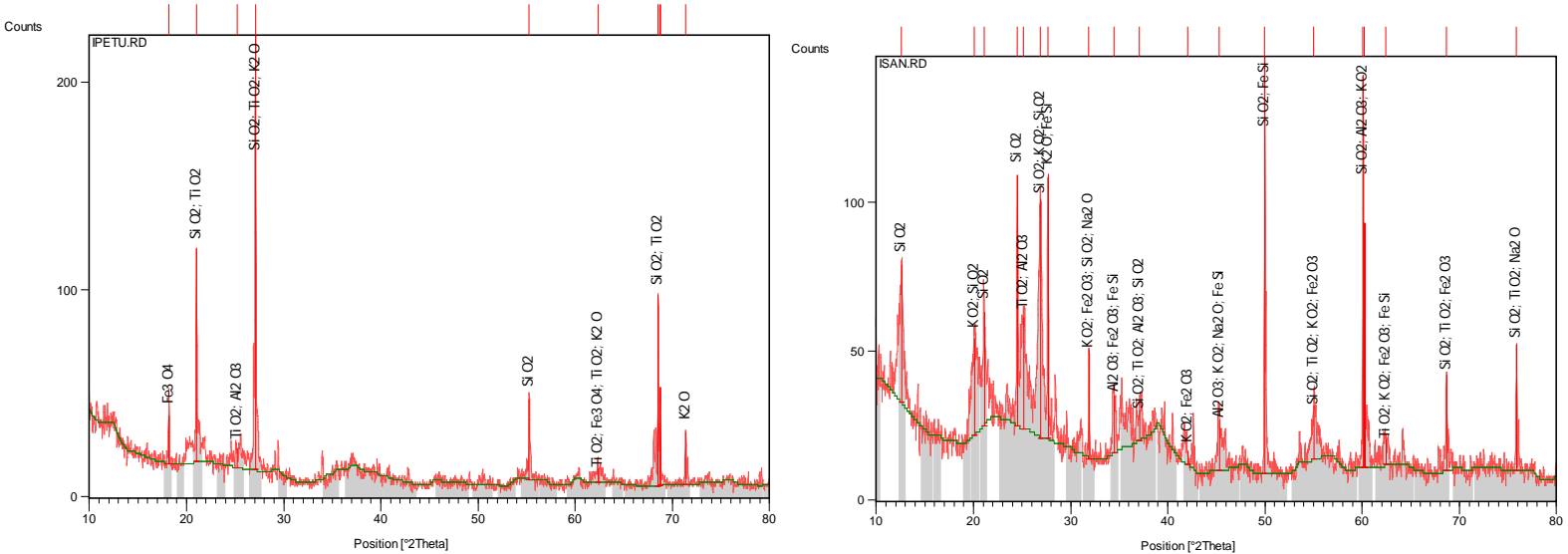

Figure 3: X-ray diffraction pattern of sample C. Figure 4: X-ray diffraction pattern of sample D 


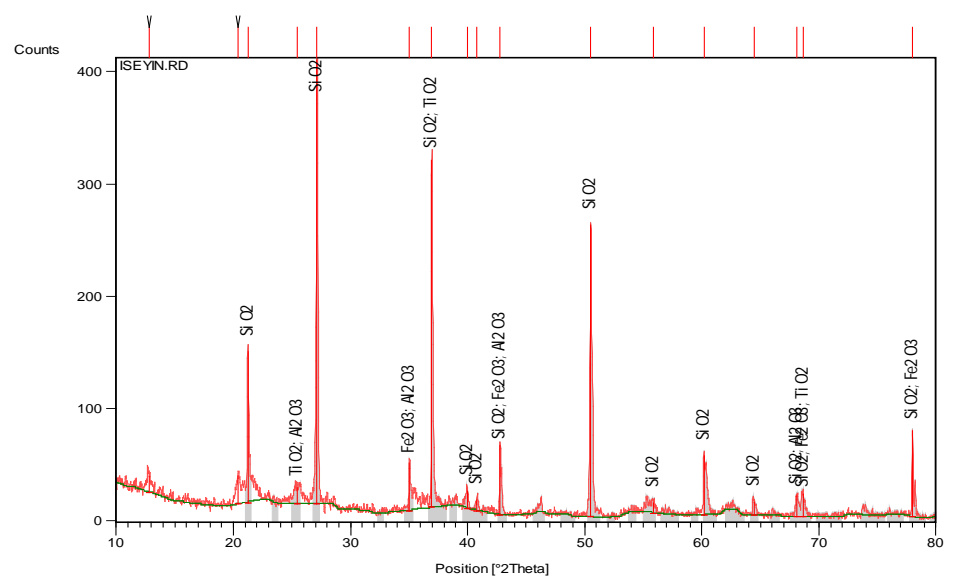

Figure 5: X-ray diffraction pattern of sample E

\subsection{XRD Analysis}

The diffractograms (Figures 1-5) show the X-ray diffraction pattern of the as-received five clay samples. Careful investigation reveals that the samples are composed essentially of $\mathrm{S}_{1} \mathrm{O}_{2}, \mathrm{Al}_{2} \mathrm{O}_{3}$, $\mathrm{Fe}_{3} \mathrm{O}_{4}$ and to very limited extent of $\mathrm{K}_{2} \mathrm{O}, \mathrm{MnO}, \mathrm{Na}_{2} \mathrm{O}$ and $\mathrm{CaO}$. Some other oxides are also present but in very negligible proportions.
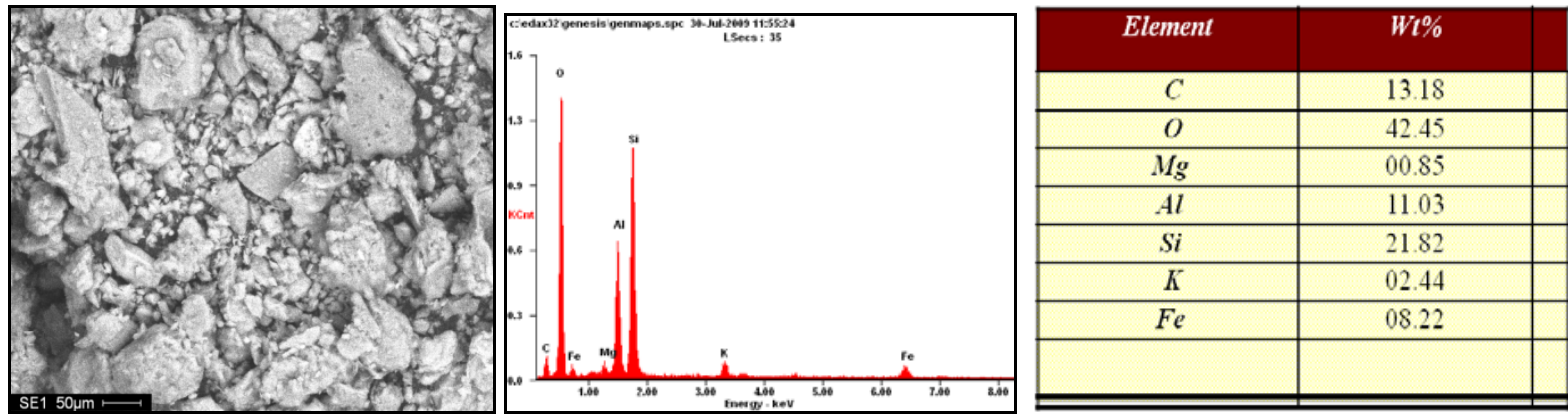

Figure 6: Typical SEM/EDX Micrographs of Sample A Showing the Morphology of the Clay and its Chemical Composition 

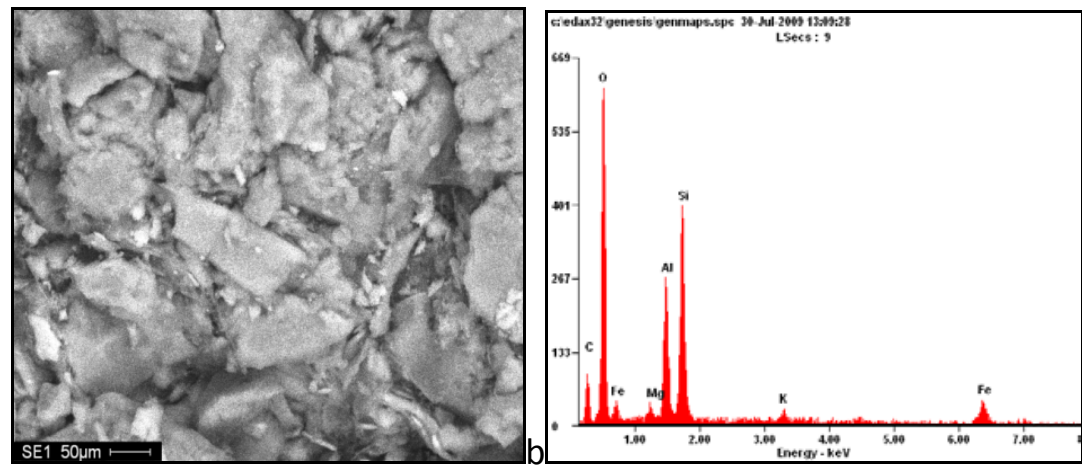

\begin{tabular}{|c|c|}
\hline Element & $\boldsymbol{W t} \%$ \\
\hline $\mathrm{C}$ & 22.54 \\
\hline$O$ & 40.45 \\
\hline $\mathrm{Mg}$ & 00.83 \\
\hline $\mathrm{Al}$ & 08.90 \\
\hline $\mathrm{Si}$ & 15.28 \\
\hline $\mathrm{K}$ & 01.51 \\
\hline $\mathrm{Fe}$ & 10.48 \\
\hline
\end{tabular}

Figure 7: Typical SEM/EDX Micrographs of Sample B Showing the Morphology of the Clay and its Chemical Composition
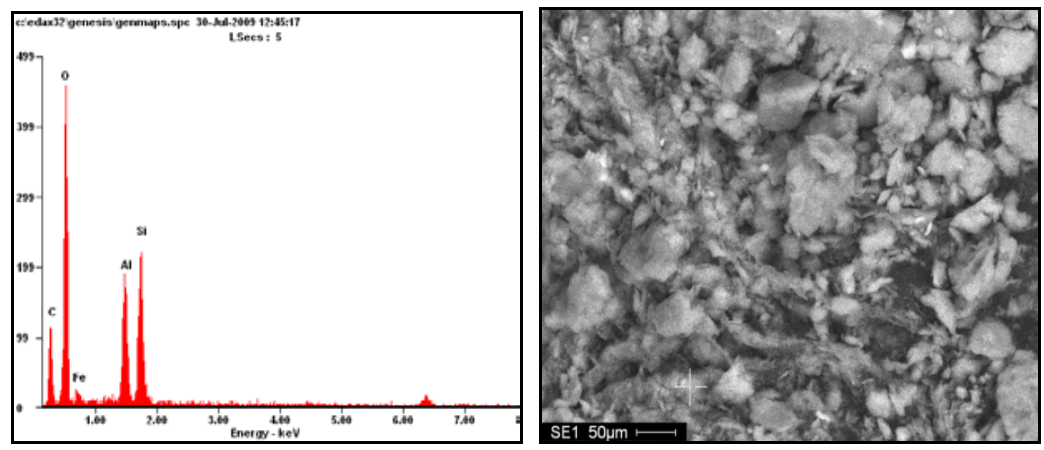

\begin{tabular}{|c|c|c|}
\hline Element & $\boldsymbol{W t} \%$ & \\
\hline $\mathrm{C}$ & 30.40 & \\
\hline$O$ & 39.57 & \\
\hline $\mathrm{Fe}$ & 09.45 & \\
\hline $\mathrm{Al}$ & 08.89 & \\
\hline $\mathrm{Si}$ & 11.68 & \\
\hline
\end{tabular}

Figure 8: Typical SEM/EDX Micrographs of Sample C Showing the Morphology of the Clay and its Chemical Composition
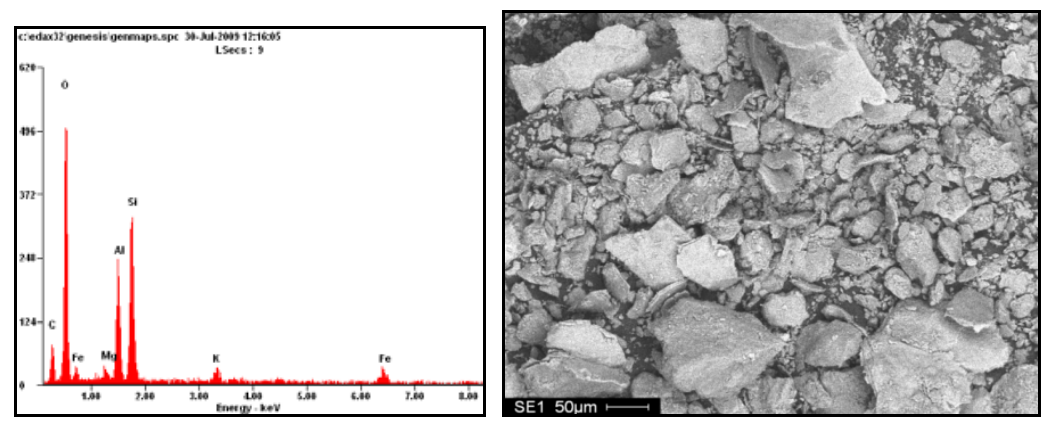

\begin{tabular}{|c|c|c|}
\hline Element & $\boldsymbol{W t} \%$ & \\
\hline$C$ & 22.41 & \\
\hline$O$ & 41.42 & \\
\hline $\boldsymbol{M g}$ & 01.08 & \\
\hline $\boldsymbol{A l}$ & 08.81 & \\
\hline $\boldsymbol{S i}$ & 15.24 & \\
\hline $\boldsymbol{K}$ & 02.12 & \\
\hline $\mathrm{Fe}$ & 08.92 & \\
\hline & & \\
\hline \hline
\end{tabular}

Figure 9: Typical SEM/EDX Micrographs of Sample D Showing the Morphology of the Clay and its Chemical Composition 

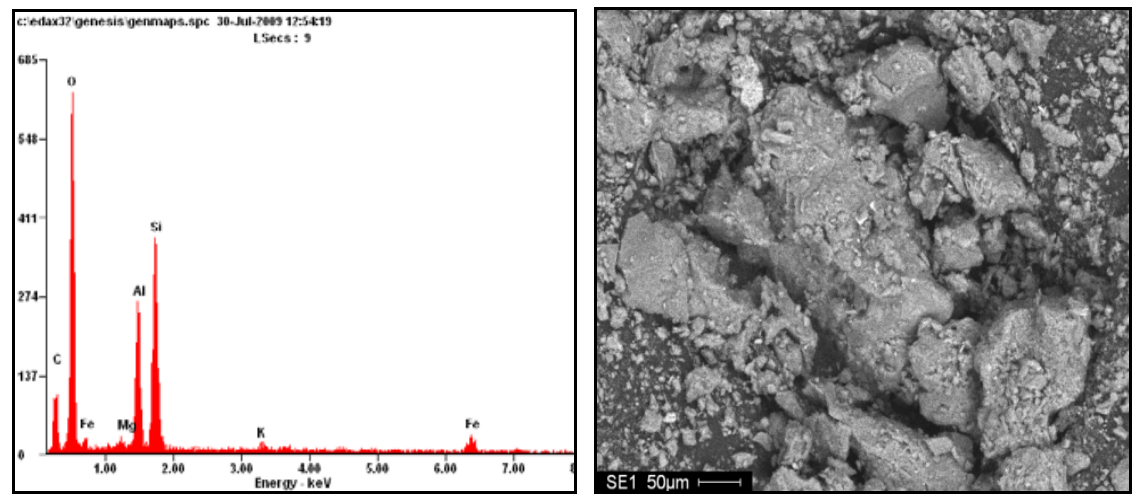

\begin{tabular}{|c|c|c|}
\hline Element & $W t^{\%}$ & \\
\hline $\mathrm{C}$ & 26.28 & \\
\hline 0 & 41.88 & \\
\hline $\mathrm{Mg}$ & 00.49 & \\
\hline $\mathrm{Al}$ & 08.91 & \\
\hline $\mathrm{Si}$ & 14.36 & \\
\hline$K$ & 00.94 & \\
\hline $\mathrm{Fe}$ & 07.13 & \\
\hline & & \\
\hline \hline
\end{tabular}

Figure 10: Typical SEM/EDX Micrographs of Sample E Showing the Morphology of the Clay and its Chemical Composition

\subsection{Scanning Electron Microscopy (SEM)}

Figures 6-10 show the different morphologies of the clays and their chemical compositions at both general surfaces and selected areas. The chemical compositions of the clays as revealed by Energy-Dispersive X-ray (EDX) analysis indicated very reasonable similarities with those of XRD and XRF.

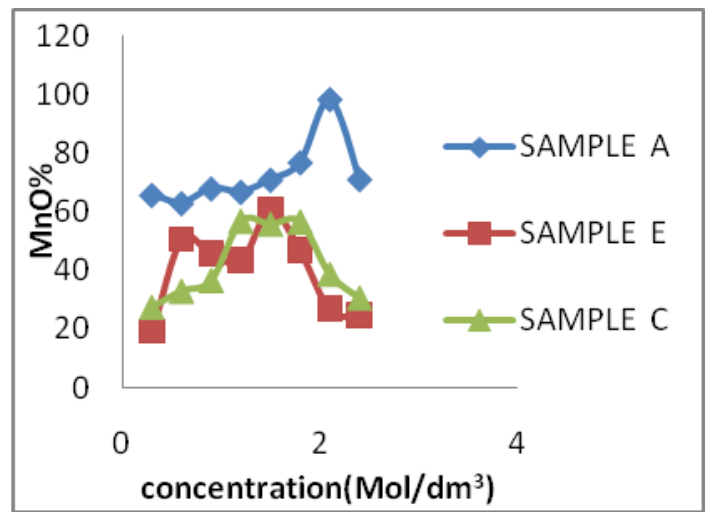

Figure 11: Variation of Manganese Oxide Removed

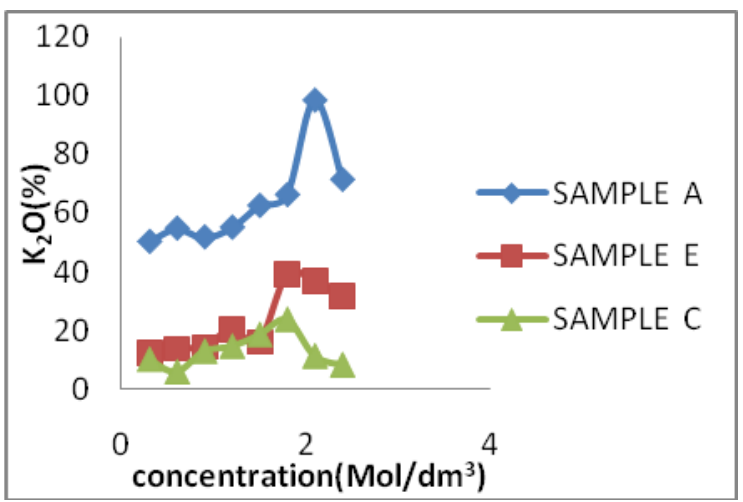

Figure 12: Variation of Potassium Oxide Removed 


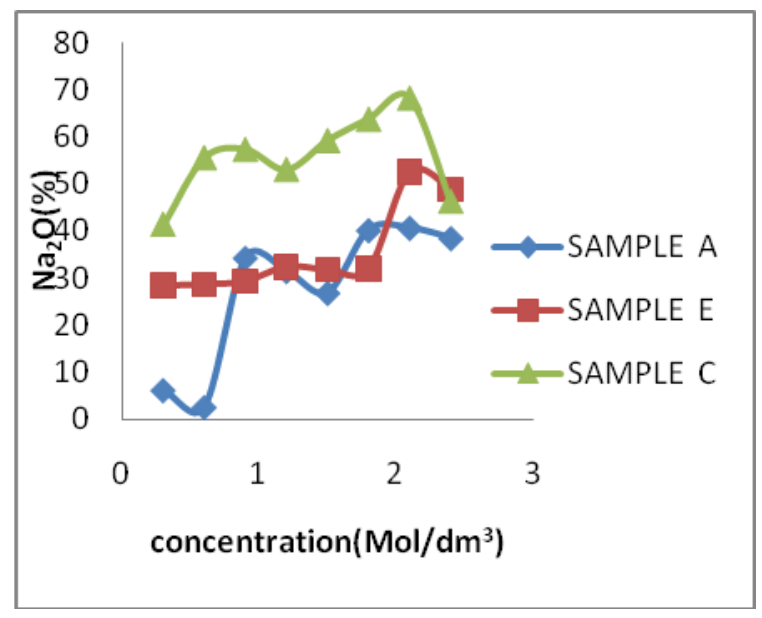

Figure 13: Variation of Sodium Oxide Removed

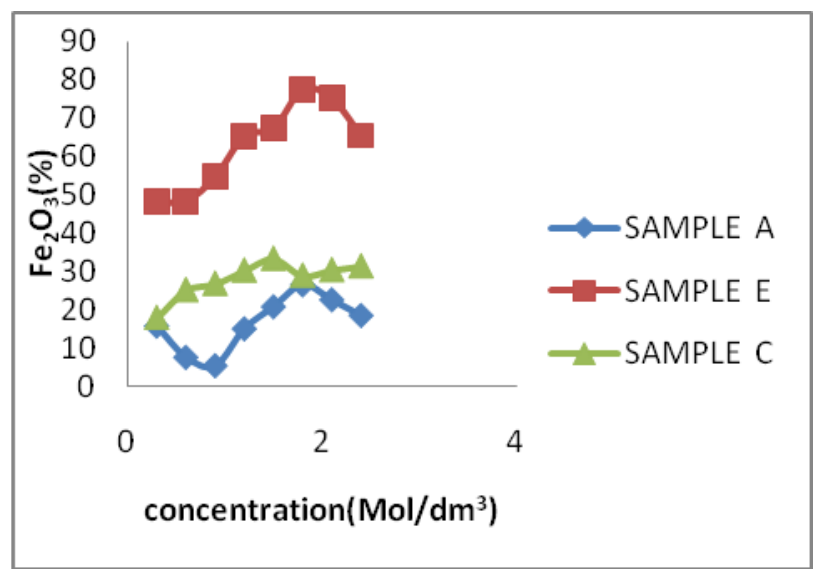

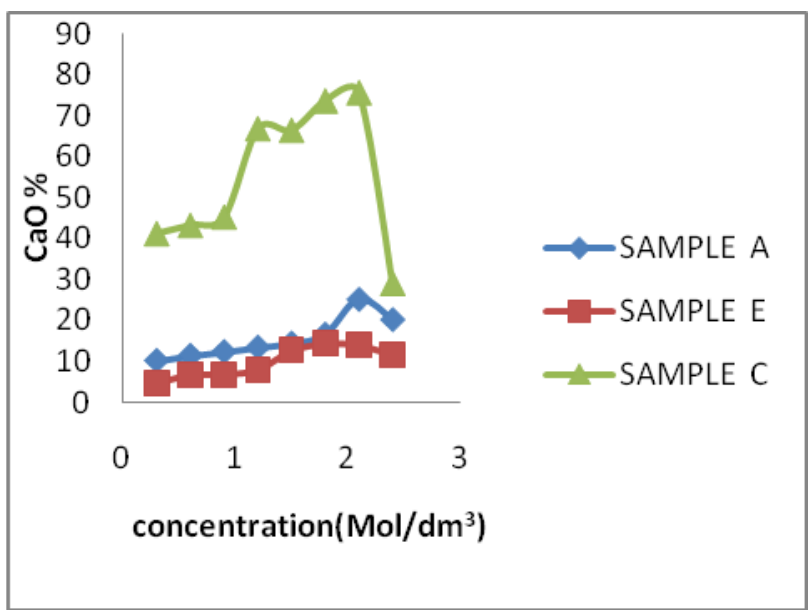

Figure 14: Variation of Calcium Oxide Removed

Figure 15: Variation of Iron oxide Removed

\subsection{Hydrometallurgical Purification}

Consequent upon the identification of the deleterious impurities as revealed by the various characterization techniques adopted, the removal was embarked upon with the use of different concentrations of oxalic acid $\left(0.3,0.6,0.9,1.2,1.5,1.8,2.1\right.$ and $\left.2.4 \mathrm{~mol} / \mathrm{dm}^{3}\right)$ at room temperature. The results as presented in figures 11 to 15 clearly show that the purification with the use of oxalic acid is an effective one, with the range of $1.8-2.1 \mathrm{~mol} / \mathrm{dm}^{3}$ of oxalic acid being the most effective concentrations for purification.

\section{CONCLUSION}


The combination of the three characterization techniques adopted in this study (XRD, XRF \& SEM/EDX) showed consistency in the revelation of the quantities of the desired elements $\left(\mathrm{Al}_{2} \mathrm{O}_{3}\right.$ and $\left.\mathrm{SiO}_{2}\right)$ and the deleterious impurities $\left(\mathrm{Fe}_{2} \mathrm{O}_{3}, \mathrm{~K}_{2} \mathrm{O}, \mathrm{MgO}, \mathrm{Na}_{2} \mathrm{O}, \mathrm{CaO}\right.$ and $\mathrm{MnO}$ ) contained in the samples. The application of oxalic acid in the purification process also showed a very reasonable degree of effectiveness, with the range $1.8-2.1 \mathrm{~mol} / \mathrm{dm}^{3}$ of the acid being the most effective concentrations for purification. The clays after purification have the potential for application in the production of acidic refractories.

\section{ACKNOWLEDGEMENT}

The authors wish to express their profound gratitude to the following bodies for their support for the research work;

- $\quad$ Federal University of Technology, Akure (F.U.T.A.)

- $\quad$ Africa Materials Science and Engineering Network (AMSEN)

- $\quad$ Regional Initiatives in Science and Education(RISE)

- $\quad$ Science Initiative Group (SIG)

\section{REFERENCES}

[1] Hassan, S.B.; "Effect of silicon carbide on some refractory properties of Kankara clay" (2001), Proceedings of Nigerian Metallurgical Society.

[2] Azom, T.; "Refractories- An overview" (2008), Journal of materials online at www.azom.com

[3] Dogan, C.P., Kwong, K.S., Bennet, J.P.; "Improved refractory materials for Slagging coal Gasifiers," (2002), in proceedings from the $27^{\text {th }}$ International conference on coal utilization and fuel systems, Clearwater, Florida.

[4] Ahmed, K.S.; "Development of Phosphate Bonded Fireclay Refractory Castable”,(1986) . Unpublished M.Sc (Chem.) Thesis, Chemical Engineering Dept., Ahmadu Bello University, Zaria, Nigeria.

[5] Hassan, S.B.;"Refractory Properties of Bauchi and Onibode Clays of Nigeria for Furnace Linning"(2000), African Journal of Science and Technology, Vol.1. No. 1, Pp. 33-41.

[6] Bakker, W.T.; "Refractories for present and future electric power plants"(1993), Key Engineering Materials, Trans Tech Publications, Vol. 88, Pp. 41-70.

[7] Ndaliman, M.B.; "Effect of certain additives on refractory properties of termite hill for furnace lining”(2000), Proc. $2^{\text {nd }}$ Ann. Engin. Conf. Federal University of Technology, Minna, Nigeria. 4-6 Sept. 2000, Pp.139-144.

[8] Borode, J.O., Onyemaobi, O.O. and Omotoyinbo, J.A.;Suitability of some Nigerian Clays as refractory raw materials(2000). Nigerian Journal of Engineering Management. Vol.3. Pp. 14-18. 